\title{
Are Gratitude and Religious Coping have impact for Psychological Well Being from Diabetes Mellitus Patients?
}

\author{
Nur Soffa ${ }^{1}$, Yunita Faela Nisa ${ }^{2}$ \\ Faculty of Psychology, Syarif Hidayatullah State Islamic University, \\ Jakarta, Indonesia \\ Nur.soffa15@mhs.uinjkt.ac.id; yunita.faela@uinjkt.ac.id
}

Keywords: Gratitude, Religious Coping, Psychological Well Being

\begin{abstract}
This study aims to determine the impact of gratitude, religious coping, social support, and gender to psychological well-being. Research partisipants are people with type two diabetes in Jabodetabek. The study involved 208 partisipants (87 men and 122 women). The Questionnaires methods used in this study was the adaptation of Psychological Well Being Scale (PWBS), The Gratitude Questionnaire-6 (GQ-6), The Brief RCOPE, and Multidimensional Scale of Perceived Social Support (MSPSS). Confirmatory Factor Analysis (CFA) is used to test the validity of each item questionnaire. Multiple regression analysis is used to see the impact of the independent variable to dependent variable. The results of this study show that there are significant impact of gratitude, religious coping, social support, and gender to psychological wellbeing. In detail, dimensions such as gratitude, positive religious coping, and negative religious coping give significant impact to psychological well being. While other dimensions such as family support, friend support, significant other support, and gender don't give significant impact to psychological well being. The suggestion for subsequent research is to use moderator or mediator variables between independent variable to psychological well being. Next suggestion is to make research using other internal or external factors of psychological well being, for example personality type, self-esteem, and culture.
\end{abstract}

Keywords: Psychological, CFA, Diabetes

\section{INTRODUCTION}

Research related to psychological well-being has been done since several years ago [1] [2] [3] [4] [5] [6] [7] [8] [9]. More than 20 years ago, studies on psychological well-being were based on the concept of positive functioning [10], which is the concept of achieving happiness consists of positive and negative effects. Then Ryff developed the psychological well-being theory by not only emphasizing the concept of achieving happiness, but also finding other indicators of positive functioning [11]. These indicators include self- acceptance, positive relationships with others, environmental mastery, autonomy, personal growth, and purpose in life [10]. Research conducted by Ryff [10] is one of the most popular studies used as a reference or guideline for researchers who are investigating psychological well-being today.

Psychological well-being is very important for humans, especially people who have a lot 
of stress in their lives. For example like patients of chronic diseases. Chronic disease is a type of degenerative disease that develops or persists for a very long period of time, caused by genetic, physiological, environmental, and behavioral factors [12]. People who suffer chronic diseases tend to have high levels of anxiety and tend to develop feelings of hopelessness and helplessness because various kinds of treatment can't help them recover from chronic disease [13]. Based on research that has been done before [14] [15] [16] [17], that chronic diseases affect the psychological well-being of patients. It's causing a decrease the level of psychological well-being.

Today, there has been an increase in the trend of chronic disease patients in Indonesia. This can be proven by looking at the result of basic health research conducted by the Indonesian Ministry of Health in 2013 and 2018. The result is an increase in the prevalence of chronic diseases including the prevalence of cancer rise from $1.4 \%$ to $1.8 \%$; stroke prevalence increased from $7 \%$ to $10.9 \%$; and chronic kidney disease rise from $2 \%$ to $3.8 \%$; diabetes mellitus rise from $6.9 \%$ to $8.5 \%$; and hypertension rise from $25.8 \%$ to $34.1 \%$. From these data researchers are very interested in people with diabetes mellitus. Although the increase in the prevalence of diabetes mellitus from the 2013 to 2018 is only $1.6 \%$. However, the number of diabetes patients actually increased rapidly to 49,442 people, and made diabetes to be the second most common disease is suffered by Indonesians in 2018 after hypertension. The latest information released by the Indonesian Ministry of Health also shows that one in eight people in Jakarta are DM patients [18]

Diabetes mellitus (DM) is a chronic disease. Diabetes mellitus is a metabolic disease characterized by an increase in blood sugar levels due to interference with insulin secretion, insulin action or both. In general, the disease is divided into two types, type one is pancreatic beta cell damage due to autoimmune, genetic or idiopathic factors and type two that generally arises due to insulin resistance related to lifestyle changes [19]. Diabetes mellitus has become one of the global public health problems. According to the International Diabetes Federation (IDF) in 2012, the number of patients is increasing in all parts of the world. According to IDF estimates (2012), more than 371 million people worldwide have diabetes mellitus, 4.8 million people died from this metabolic disease and 471 billion US dollars spent on the treatment.

Based on the research that has been done previously [14] [15] [16] [17], shows that chronic diseases affect the psychological well-being of patients. Anggraeni \& Ika [15] also found that people with diabetes mellitus experienced an increase in psychological disorders, especially for patients who had experienced complications. Because people with type two diabetes mellitus have tough life related to the disease they suffer which often causes stress, thus affecting their psychological well-being. Therefore, researchers are interested in examining the psychological well-being of people with type two diabetes mellitus.

Psychological well-being is the ability of individuals in self-acceptance, positive relationships with others, personal growth, life goals, environmental mastery, and independence [10] [20]. Ryff [21] added that psychological well-being is one of the most important things that must be had, because it can help reduce the level of depression in oneself. Factors that can affect psychological well-being are age, sex, socioeconomic, and culture [22]. In addition there are other factors such as social support [23] [24], gratitude [25] [26] [9] [8], and personality [26]. These factors can help someone to improve their psychological well-being.

Patients with type two diabetes mellitus will experience a process of transition from healthy to sick condition. This can affect their the psychological well-being. According to Tristiana et al [27] since the beginning of knowing the diagnosis of this disease, patients will experience a loss response through five stages, they are denying, angry, bargaining, 
depression, and accepting. Diabetes patients' acceptance of their illness is closely related to gratitude. Then the aspect of gratitude is very important for diabetes patients, in order to improve their psychological well-being.

Diabetes is one of stressors source for patients. Because this disease involves changes in lifestyle, diet, frequent medical examinations, medications and serious complications. All of these components can affect the psychological well-being of patients with diabetes [28]. Therefore diabetes patients need religious coping methods in order to help reduce their stress and improve their psychological well-being in order to avoid complications.

Social support from the closest people is needed to improve the psychological well-being of diabetes patients. Social support is an interpersonal relationship in retrieving information, emotional attention, evaluation, and instrumental assistance through interaction with the environment. This relationship has emotional benefits or behavioral effects on a person, to help him overcome his problems [23].

Psychological aspect is one of the important things to be considered by diabetics because belief in health, knowledge, and behavior in patients with diabetes mellitus will affect DM patients in controlling their disease [27]. One of the aspect is psychological well- being. Psychological well-being is very important to be studied because it has a positive correlation with a person's physical health condition [29] and can help improve the treatment process. Therefore, the study will examine the effect of gratitude, religious coping, social support and gender on the psychological well-being of people with type two diabetes mellitus.

Although psychological well-being has been investigated in previous studies [27] [30] [9] [5], these studies only use qualitative and experimental methods, besides the subject of research only focuses on the regions of Yogyakarta and East Java. This research uses quantitative methods and research subjects used are people with type two diabetes mellitus in Jakarta. Jabodetabek was chosen because of the rapid growth of type 2 diabetes mellitus patients in the region. Therefore, the study will examine the effect of gratitude, religious coping, social support and gender on the psychological well-being of people with type two diabetes mellitus.

\section{LITERATURE REVIEW}

\subsection{Psychological Well Being}

From the definitions that have been presented by experts regarding psychological wellbeing, that psychological well-being is an individual's ability to have a positive perception of himself and can have meaning and purpose in life. In this study researchers used a definition from Ryff [10]. The definition was chosen because it is appropriate with the purpose of the study.

In this study, researchers chose to use the dimensions proposed by Ryff [10]. These dimensions were chosen, based on the theory that used in this study. According to Ryff [10], there are several dimensions in psychological well-being, they are self-acceptance, positive relations with other, autonomy, environmental mastery, purpose in life, and personal growth.

\subsection{Gratitude}

Based on the definition of gratitude by experts, that gratitude is a tendency to express gratitude in response to the reception of positive emotions and then develop into attitudes and behaviors that can affect one's reaction in dealing with something or situation in his life. This definition is appropriate with the opinion of McCullough \& Emmons [31]. The definition was chosen because it is appropriate with the purpose of the study. 
In this study, researchers chose to use the dimensions proposed by McCullough, Emmons, Tsung [31]. According to McCullough, Emmons, and Tsung [31] the dimension of gratitude consists of three things are intensity, frequency, and density. These dimensions were chosen because they are appropriate with the theory that used in this study.

\subsection{Religious Coping}

Based on the explanation related to the definition of religious coping by experts. Religious coping is a way for someone to deal with stress (coping) using religious methods. In this study the definition of religious coping chosen was according to Pargament [32]. The definition was chosen because it is appropriate the purpose of the study.

In this study, the dimensions of religious coping use the dimensions proposed by Pargament et al [33]. According to Pargament et al [33], religious coping has both positive and negative aspects. Positive religious coping aspects include benevolent religious reappraisal, collaborative religious coping, seeking spiritual support, religious purification, spiritual connection, seeking support from clergy or members, religious helping, and religious forgiving. While negative religious coping includes punishing god reappraisal, demonic reappraisal, reappraisal of god's power, self-directing religious coping, spiritual discontent, interpersonal religious discontent. These dimensions were chosen because they best fit the definition used in this study.

\subsection{Social Support}

Based on the explanation of definitions by experts. Social support is support given by others, such as family, friends and significant others who can make someone feel loved, cared, and precious. In this study used the definition of social support by Zimet \& Dahlem [34]. Because this definition is appropriate with the purpose of the study.

In this study the dimension of social support used the dimension proposed by Zimet and Dahlem [34]. According to Zimet and Dahlem [34] there are three dimensions of social support are family support, friend support, and significant other support.

\section{METHOD}

The population in this study is people with diabetes mellitus in Jakarta. The sample in this study are 209 people with type two diabetes mellitus who lived in Jakarta. The sampling technique used in this study is a non-probability sampling technique. In this technique every element in the population does not have the same opportunity to be sampled, even the probability is unknown. The sampling technique used is convenience sampling, which is a method of determining samples based on accidental, members of the population met by researchers, and willing to be respondents. Multiple regression analysis is used to see the impact of the independent variable to dependent variable

Psychological well-being is measured using the Psychological Well Being Scale (PWBS) made by Ryff \& Keyes [20]. PWBS consists of 18 items. This scale provides seven choices of rating scale answers ranging from 1 to 7 .

Gratitude is measured using the Gratitude Questionnaire (GQ-6), created by McCullough, Emmons, and Tsung [31]. The Gratitude Questionnaire (GQ-6) consists of 6 items. This scale provides seven choices of rating scale answers ranging from 1 to 7 .

Religious coping was measured using The Brief RCOPE made by Pargament, Feuille, and Burdzy [35]. The RCOPE Brief consists of 14 items. This scale provides four choices of rating 
scale answers ranging from 1 to 4 .

Social support was measured using the Multidimensional Scale of Perceived Social Support (MSPSS) created by Zimet and Dahlem [34]. MSPSS consists of 12 items. This scale provides seven choices of rating scale answers ranging from 1 to 7 .

\section{RESULT}

The number of samples is 209 respondents. Among them, it is known that the most respondents were 122 women $(58.4 \%)$. Based on age, the majority of respondents were middle adulthood with an age range of 41-60 years as many as 102 (48.8\%). Respondents in this study were predominantly Muslim, totaling 203 (97.1\%). Based on the level of education, the most respondents were tertiary institutions totaling 93 (44.5\%). Based on the length of diagnosis, most respondents who were diagnosed for less than 5 years were $134(64.1 \%)$.

R-Square of 0.273 or $27.3 \%$ were obtained. This means that the proportion of the variance of psychological well-being explained by all independent variables is $27.3 \%$ while $72.7 \%$ is influenced by other variables outside this study.

\section{CONCLUSION}

Based on the results of the research described in the previous chapter, the conclusion of this study is "there is a significant impact on variables of gratitude, religious coping (positive religious coping and negative religious coping), social support (family support, friend support, and significant other support ), and gender on psychological well-being".

The results of testing the effect of each independent variable on the dependent variable (psychological well-being) showed that there were 3 variables that had significant influence, they are gratitude, positive religious coping, and negative religious coping. Whereas the other 4 variables have non- significant regression coefficient values, they are family support, friend support, other significant support, and demographic factors (gender).

\section{DISCUSSION}

This study aims to look at the effects of variables of gratitude, religious coping, social support, and gender on psychological well-being. The results showed that gratitude, religious coping, social support, and gender together significantly influenced psychological well-being.

The results of this study also showed that the psychological well-being of diabetics was in the high category. Psychological well-being has an important role for people with type 2 diabetes mellitus. Research conducted by Garushi et al [36] explains that high psychological well-being can affect sufficient glycemic control, good self- control, and low risk of complications due to diabetes. This can happen if people with type 2 diabetes mellitus are willing to accept him with all the advantages and disadvantages including the disease he is suffering from. When people with type 2 diabetes have been able to accept themselves, so patients with type 2 diabetes will pay attention and control their blood sugar levels. So that it can reduce the risk of complications due to diabetes.

The variable gratitude is one of the internal factors that can affect psychological wellbeing. The results showed that the variable gratitude has a significant influence on psychological well-being. This is suitable with research conducted by Behzadipour et al [8] which states that gratitude is highly correlated with psychological well-being.

Another internal factor is the religious coping variable. Religious coping is a coping strategy with a religious approach. In this study, the two dimensions of religious coping are positive religious coping and negative religious coping have a significant effect on 
psychological well-being. The positive religious coping dimension has a significant influence on psychological well-being. This is in line with research conducted by Gholamzadeh, et al [7] which states that higher the positive religious coping, the level of psychological well-being is higher too. The negative religious coping dimension also has a significant influence on psychological well-being, but the direction of the regression coefficient is negative. This is suitable with research conducted by Gholamzadeh, et al [7] which states that negative religious coping is negatively correlated with psychological well-being, where the lower the negative religious coping the higher the level of psychological well-being possessed.

The social support variable is one of the external factors studied. Social support consists of three dimensions, namely social support obtained from family, social support obtained from friends, and social support obtained from significant others. The results of this study indicate that social support does not significantly influence psychological well-being. The dimension of family support has no significant effect on psychological well-being. This insignificant result is likely to occur because most of the respondents are in middle adult age and elderly who live separately from their families. So that makes patients of type 2 DM are independent and can take care of themselves without the help of others. In addition, research conducted by Khaerani [37] also shows that there is no significant effect on the dimensions of family support for psycholofical well-being.

The dimension of friend support also does not have a significant effect on psychological well- being. The results of research conducted by Khaerani [37] stated that there was no significant influence of peer support on psychological well- being. Khaerani [37] also added that the result was not significant because of a feeling of unwillingness and repayment to others in this case it was a friend.

Other significant support dimensions also do not have a significant influence on psychological well- being. This is appropriate with Khaerani's research [37] which states that there is no significant influence of other significant supports on psychological well-being.

Previous research conducted by Karsel et al [5] states that there is a significant influence of social support variables on psychological well-being through mediating diabetes related coping variables. This is indeed in line with the results of this study, where there is no significant direct effect of social support on psychological well-being.

The gender variable does not have a significant effect on psychological well-being. These findings can be caused by the condition of diabetics both women and men there is no difference. This was also shown in a previous study conducted by Zahara [17] state that there was no difference between the psychological well-being of men and women.

In this study the results indicate that internal factors have a significant effect compared to external factors. This can be occured because internal factors such as gratitude and religious coping can be controlled directly by the individual. So that the individual can feel a greater influence compared to external factors.

Overall, the results of this study need to be further developed in order to get comprehensive results. Insignificant results can be caused because these variables do not affect directly. However, it may be necessary for a moderator or mediator so that these variables can affect.

Based on the research process and results obtained, the researcher realizes that there are some lacks in this study. The researcher provides several suggestions which include theoretical and practical suggestions. Suggestions for this research are to improve further research related to the topic of psychological well-being.

The results of this study indicate that the significant variable is an internal factor of psychological well-being, such as gratitude and religious coping. Therefore, researchers 
suggest that they can use another internal factors of psychological well-being in future studies. Researchers suggest making research by adding diabetes related coping variables as moderators of social support variables for psychological well- being.

The results of the study show that gratitude has a significant influence on the psychological well-being of people with type 2 diabetes mellitus. Therefore, researchers suggest that people with type 2 diabetes mellitus can increase their gratitude by digging up information related to productive and useful lives with DM. So that people with DM can accept the disease. Searching for this information can be obtained through workshops, seminars, watching videos on YouTube, and actively participating in activities in DM patients groups in order to exchange information and share feelings with fellow patients of DM.

In addition, in this study there is also a significant influence of religious coping both positive and negative on the psychological well- being of people with type 2 diabetes mellitus. Researchers suggest that patients of type 2 diabetes mellitus can increase religious coping positive by doing religious activities. It is also expected to reduce the level of negative religious coping by having positive thinking about God and religion. 


\section{REFERENCES}

[1] Felton, B. J., \& Revenson, T.A. (1984). Coping with chronic illness: A study of illness controllability and the influence of coping strategis on psychological adjustment. Journal of Consulting and Clinical Psychology, 52(3), 343-353. doi: 10.1037/0022006X.52.3.343

[2] Petersen, L.R., \& Roy, A. (1985). Religiosity, anxiety, meaning, and purpose: Religion's consequences for psychological well-being. Review of Religious Research, 27(1), 49- 62. doi: 10.2307/3511937

[3] Hassmen, P., Koivula, N., \& Uutela, A. (2000). Physical exercise and psychological well being: A population study in Finland. Preventive Medicine, 30, 17-25. doi: 10.1006/pmed.1999.0597

[4] Eiser, J. R., Riazi, A., Eiser, C., Hammersley, S.,\& Tooke, J.E. (2001). Predictors of psychological well-being in types 1 and 2 diabetes. Psychology and Health, 16, 99-110

[5] Karsel, B., Idsoe, T., Hanestad, B., Murberg, T., \& Bru, E. (2004). Perceptions of support, diabetes-related coping, and psychological well-being in adult with type 1 and type 2 diabetes. Psychology, Health, and Medicine, 9(1). doi: 10.1080/13548500310001637751

[6] Wood, A.M., Joseph, S., \& Maltby, J. (2009). Gratitude predict psychological wellbeing above the big five facets. Personality and Individual Differences, 46, 443-337. doi: 10.1016/j.paid.2008.11.012

[7] Gholamzadeh, S., Hamid, T.A, Basri, H., Sharif, \& Ibrahim, R. (2014). Religious coping and psychological well-being among iranian stroke caregivers. Iranian Journal of Nursing and Midwifery Research, 19(5), 478-484 retrieved from https://www.ncbi.nml. nih.gov/pmc/articles/PMC4223964/ on 12 Desember 2018

[8] Behzadipour, S., Sadeghi, A., \& Sepahmansour, M. (2016). A study on the effect of gratitude on happiness and well-being. Asian Journal of Health Psychology, 1(2), 65-72

[9] Akbar, R.M. (2018). Hubungan kebersyukuran dengan psychological well-being pada pasien yang mengidap penyakit diabetes mellitus tipe 2. Skripsi. Fakultas Psikologi dan Ilmu Sosial Budaya Islam Indonesia

[10] Ryff, C.D. (1989). Happiness is everything, or is it? Exploration on the meaning of psychological well-being. Journal of Personality and Social Psychology, 57(6), 10691081

[11] Ryan, R.M., \& Deci, E.L. (2001). On happiness and human potentials: A review of research on hedonic and eudaimonic well-being. Annual Review Psychology, 52, 141166

[13] Sarafino, E.P., \& Smith, T.W. (2011). Health psychology:Biopsychosocial interaction 7th edition. USA: John Wiley \& Sons Inc.

[14] Karyono, Dewi, K.S., Lela, T.a. (2009). Penanganan stress dan kesejahteraan psikologis pasien kanker payudaya yang mengalami radioterapi di RSUD Dr. Moewardi 
Surakarta. Media Media Indonesia, 43(2), 102-105. Retrieved from: http//www.mediamedika.net on 29 Desember 2018

[15] Anggraeni, T., \& Ika, Y. C. (2012). Perbedaan psychological well-being pada penderita diabetes mellitus tipe dua usia dewasa madya ditinjau dari strategi coping. Journal Psikologi Klinis dan Kesehatan Mental, 1(2), 78-86. Retrieved from: journal.unair.ac.id/ filerPDF/jpkkb86494431afull.pdf on 29 Desember 2018

[16] Wahyuningsih, A., \& Surjaningrum, E.R. (2012). Kesejahteraan psikologis pada orang dengan lupus wanita usia dewasa awal berstatus menikah. Jurnal Psikologi Klinis dan Kesehatan Mental, 1(3), 154-161

[18] Kementrian Kesehatan RI. (2018). Potret sehat Indonesia dari riskesdas 2018. $\begin{array}{lllll}\text { Diunduh } & \text { paada } & 29 & \text { Desember }\end{array}$ http://www.depkes.go.id/article/view/18110200003/potret-sehat-indonesia-daririskesdas-2018.html

[20] Ryff, C.D., \& Keyes, C.L.M. (1995). The stucture of psychological well-being revisited. Journal Personality and Social Psychology, 69(4), 719-727

[21] Ryff, C.D., \& Singer, B.H. (eds). Series in affective science. Emotion, social relationship, and health. New York: Oxford University Press doi: 10.1093/acprof:oso/97801951454

[22] Ryff, C.D. (1995). Psychological well-being in adult life. Current Direction in Psychological Science, 4(4), 99-104

[23] Desiningrum, D.R. (2010). Family's social support and psychological well-being of elderly in tembalang. Anima, Indonesian Psychological Journal, 26(1), 61-68

[26] Nurani, F. (2016). Pengaruh rasa syukur dan kepribadian terhadap psychological well-being Orang tua yang memiliki anak berkebutuhan khusus. Skripsi. Fakultas Psikologi UIN Jakarta

[27] Tristiana, R.D., Kusnanto, Widyawati, I.Y., Yusuf, A., \& Fitryasari, R. (2016). Kesejahteraan psikologis pada pasien diabetes mellitus tipe 2 di puskesmas mulyorejo surabaya. Journal Ners, 11(2), 147-156

[28] Tirumalesh, M., \& Chandaian, K. (2017). Psychological well-being among diabetes melliatus patients. International Journal of Management and Applied Science, 3(8)

[29] Temane, Q.M., \& Wissing, M.P. (2006). The role of subjective perception of health in the dynamics of context and psychological well- being. South African Journal of Psychology, 36(3),564-581.doi: 10.1177/008124630603

[30] Sudjana, R.C., Wahyuningsih, H., \& Uyun, Q. (2015). Peningkatan kesejahteraan psikologis pada penderita diabetes mellitus tipe 2 dengan menggunakan group positive psychotherapy. Jurnal Intervensi Psikologi, 7(2), 215-232600308

[31] McCulllullough, M.E., Emmons, R.A., \& Tsang, J. (2002). The grateful disposition: A conceptual and empirical topography. Journal of Personality and Social Psychology, 82(1), 112-127. doi: 10.1037//0022-3514.82.1.112

[32] Pargament, K.I. (1999). The psychology of religion and spirituality? Yes and no. International Journal for the Psychology of Religion, 9(1), 3-16 doi: 10.1207/s15327582ijpr0901_2 
[33] Pargament, K.I., Harrison, M.O., Koenig, H.G., Hays, A.G., \& Akwari, E. (2001).The epidemiology of religious coping: a review of recent literature. International Review of Psychiatry, 13, 86-93

[34] Zimet, G.D., Dahlem, N.W., Zimet, S.G., \& Farley, G.K. (1988). The multidimensitional scale of perceived social support. Journal of Personality Asessment, 52(1), 30-41. doi: 10.1207/s15327752jpa5201_2

[35] Pargament, K.I., Feuille, M., \& Burdzy, D. (2011). T he brief RCOPE: Current psychometric status of a short measure of religious coping. Religion, 2, 51-76. doi: 10.3390/rel2010051

[36] Garushi, B., Baneshi, M.R.,\& Moradi, S. (2013). Psychosocial contributing factors that affect mental wellbeing in diabetic patients. Russian Open Medical Jurnal, 2, 1-5 [37] Khairani, A.C. (2015). Peran persepsi dukungan sosial dan religiusitas terhadap kesejahteraan psikologis pasien paraplegia. Tesis. Fakultas Psikologi Universitas Gajah Mada 